\title{
SOME FACTORS AFFECTING THE SUSCEPTIBLITY OF COTTONSEED TO Macrophomina phaseolina
}

Abdel-Sattar, M.A. ${ }^{1}$, A.A. Aly ${ }^{2}$, and M.R. Omar ${ }^{2}$

${ }_{1}^{1}$ Dept. of Agric. Bot., Fac. of Agric., Suez Canal Univ., Ismailia, Egypt.

2 Plant Pathology Research Institute, Agric. Res. Center, Giza, Egypt.

\begin{abstract}
Colonization of cottonseed by $M$. phaseolina during the early stages of infection was affected by inoculum density, temperature, incubation period (time of seed exposure to inoculum), and pathogenicity of isolates. The higher the inoculum density, the earlier the isolation of $M$. phaseolina from seeds and the higher its isolation frequency. The three main effects of ANOVA (temperature, incubation period, and isolate) were all very highly significant sources of variation in isolation frequency of $M$. phaseolina from seeds regardless of the tested cultivar (Giza 75, Giza 80, or Giza 85). Temperature $\mathrm{x}$ incubation period interaction was a very highly significant source of variation in isolation frequency from Giza $75(P=0.0000)$ and Giza $80(P=0.0001)$, while it was a nonsignificant source of variation $(P=0.2925)$ in isolation frequency from Giza 85. All the other source of variation were nonsignificant $(P>0.05)$ regardless of the tested cultivar.
\end{abstract}

\section{INTRODUCTION}

Macrophomina phaseolina (Tassi) Goid., the causal agent of charcoal rot on cotton, is a seedborne and soilborne pathogen with a wide distribution and a wide host range (Dhingra and Sinclair, 1978). When M. phaseolina invades roots or stems of cotton, colonization of internal tissues proceeds rapidly and the plant dies. Examination of affected parts reveals a dry rot, with many tiny black sclerotia distributed throughout the wood and softer tissues (Watkins, 1981).

We believe that the importance of $M$. phaseolina, as a cotton pathogen, is underestimated in Egypt. This view has come from the observation that during the last 50 years, $M$. phaseolina on cotton was almost completely absent from the literature of cotton diseases in Egypt. Thus, a handful of research papers, most of them not dealing with $M$. phaseolina per se, were found in this literature (Mostafa et al., 1957; Mostafa et al., 1959; Mohamed, 1962; Sabet and Khan, 1969; and Omar, 1999). This lack of concern is not justifiable because this fungus is of widespread distribution in the Egyption soil and it is easily and frequently isolated from cotton roots particularly during the late period of the growing season. Thus, when Aly et al. (1996) conducted a survey encompassed 88 samples of infected cotton roots from 12 Egyptian governorates. M. phaseolina was isolated from $37.5 \%$ of the samples examined.

Susceptibility of cotton, as well as other crops, to $M$. phaseolina is markedly affected by the prevailing environmental conditions and such effects are well documented in the literature. 


\section{Inoculum density}

Rana and Tripathi (1984) found that increased density/unit area of $M$. phaseolina inoculum (sand-oat meal or homogenized mycelia suspension) led to increased collar rot in Indian mustard (Brassica juncea). Younger inoculum was more virulent than older mycelium. When Pineda et al. (1985) placed sesame seeds in plastic containers filled with autoclaved soil and covered them with soil containing sclerotia of $M$. phaseolina, they found that at 1000 sclerotia/g soil, germination was reduced in 2 of 3 cultivars. Plant mortality, especially of 50 and 60-day-old seedlings, was higher at 333 and 500 sclerotia/g soil than at $200 / \mathrm{g}$. Severe damage thus occurred at the densities tested and might be expected at lower densities in naturally infested soils. Hooda and Crover (1988) found that increase in inoculum quantity of $M$. phaseolina led to greater disease incidence on mungbean (Vigna radiate) and accordingly required higher concentrations of fungicides for control. Gupta and Cheema (1990) mentioned that microsclerotia of M. phaseolina present on sesame seeds were positively correlated with plant infection and negatively correlated with seed germination, dry matter production, and root and shoot length of seedlings. Umamaheswari et al., (2000) investigated the effect of inoculum levels, 500 and 1000 sclerotia/kg soil, on the incidence of dry root rot (M. phaseolina) of groundnut, grown in sterilized and unsterilized soil. They observed a significant increase in disease incidence (48.7 and $98.5 \%$ ) with increasing inoculum level from 500 to 1000 sclerotia $/ \mathrm{kg}$ of unsterilized and sterilized soil, respectively. Rettinasababady et al. (2000) treated seeds of blackgram (Vigna mungo) cv. ADT with different inoculum levels of $M$. phaseolina $(0,2,5$, and $10 \%)$. The number of plants showing progressive root rot was counted 15, 30, 45, and 60 days after sowing. The lowest seed germination percentage was at $10 \%$ inoculum level. There was a significant increase in root rot incidence that was directly proportional to the increase in plant age. Forty five and 60-day-old plants were severely affected by the pathogen.

\section{Temperature}

Patel and Patel (1990) studied meteorological correlation of charcoal-rot of sesame. They found that optimum temperature for growth and sclerotia formation by $M$. phaseolina was $35^{\circ} \mathrm{C}$, both declined at temperature below $15^{\circ}$ and above $40^{\circ} \mathrm{C}$. Under field conditions, disease intensity increased with a progressive rise in temperature. Mukhopadhyay et al. (1991) mentioned that low temperature $\left(25^{\circ} \mathrm{C}\right)$ favoured damping-off of mungbean seedlings in pots of soil with maize meal-sand inoculum of $M$. phaseolina. Manici et al. (1995) investigated temperature responses of 64 isolates of $M$. phaseolina from different climatic regions of sunflower production in Italy. The isolates were subjected to growth rate (GR) tests at $15,25,30,35$, and $40^{\circ} \mathrm{C}$. The optimum temperature for growth was $30^{\circ} \mathrm{C}$ for 62 isolates and $35^{\circ} \mathrm{C}$ for 2 isolates. Isolate $G R$ varied considerably at all temperatures $(P<0.01)$ but the maximum variability between isolates occurred at 15 and $40^{\circ} \mathrm{C}$. Isolates from the north (colder area) grew better at lower temperature than other isolates and also showed a good adaptability to $40^{\circ} \mathrm{C}$. Isolates from the midwest (Mediterranean climate) had the faster GR at $40^{\circ} \mathrm{C}$ but the worst GR at the lowest temperature tested. Isolates from the mideast and south, with 
Mediterranean climate, grew better at the optimum temperature (30 and $35^{\circ} \mathrm{C}$ ) and showed the poorest adaptability to the limit temperature (15 and $40^{\circ} \mathrm{C}$ ). Viana and De-Souza (1997) conducted a study to investigate the effects of temperature on sclerotial germination of $M$. phaseolina under laboratory conditions. The tested temperatures were 30,40 and $50^{\circ} \mathrm{C}$. The results indicated that the temperature significantly affected germination of microsclerotia and that the greatest percentage germination was obtained at $30^{\circ} \mathrm{C}$. The role of temperature on ashy gray blight of cowpea was studied by Ratnoo et al. (1997a) in pot experiment. Seeded pots were subjected to 4 temperature regimes, $10-25,15-30,20-35$, and $25-40^{\circ} \mathrm{C}$. The results clearly indicated that the disease development was most favoured by higher temperatures. All the plants developed the disease in temperature regime of $25-40$ and $20-35^{\circ} \mathrm{C}$ with respective disease indices of 100 and $94.5 \%$. Omar (1999) found that the optimal temperature for pathogenicity of $M$. phaseolina on cotton was somewhere between $24.5 \pm 1.5$ to $38.0 \pm 2.0^{\circ} \mathrm{C}$. Viana and deSouza (2002) evaluated the effect of five temperatures $(24,27,30,33$ and $39^{\circ} \mathrm{C}$ ) on the germination of microsclerotia of $M$. phaseolina in sand substratum under laboratory conditions. The results showed $(P<0.05)$ that the greatest percentage of germination occurred at 30 and $33^{\circ} \mathrm{C}$.

Inoculum quality (Variability in pathogenicity among isolates of $M$. phaseolina)

Lee et al. (1986) tested isolates of $M$. phaseolina from bean, cotton and groundnut for pathogenicity on cotton. There were some variations in resistance but all isolates infected cotton. Pearson and Schwerk (1986) found that the isolates of $M$. phaseolina from maize grew on a medium with potassium chlorate, but the isolates from soybean did not. They postulated that these differences might reflect metabolic activities associated with host specialization. Diourte (1987) inoculated sorghum, groundnut, bean and cotton with isolates from each of these hosts. There was a general trend to host preference for the same-host isolate. Vilela et al. (1987) tested 18 isolates of $M$. phaseolina causing charcoal rot in cotton. Significant differences in many characters were found but all isolates were highly pathogenic to cotton in Northern Peru. Diourte et al. (1995) found that an isolate of M. phaseolina originally isolated from sorghum genotype with resistance to charcoal rot caused greater symptoms development than did two other isolates originally obtained from sorghum genotype susceptible to charcoal rot. Ratnoo et al. (1997b) established two isolate types (M1 and M2) of M. phaseolina isolated from cowpea. The isolate M2 was more virulent with a disease index of $86.11 \%$ compared with M1 (77.7\%). M2 produced symptoms in 7-10 days and blighted the plants in 10-15 days, whereas M1 produced symptoms in 9-14 days and blighting in 25-35 days. Mayek-Perez et al. (1997) determined variation in in vitro cultural characteristics and virulence to common beans (Phaseolus vulgaris) of $15 \mathrm{M}$. phaseolina isolates obtained from different hosts and geographical areas in Mexico. Results showed that quantitative characteristics such as in vitro relative growth rate of the colony, are an appropriate tool to characterize the pathogen' development. M. phaseolina isolates obtained from other hosts such as sesame, sorghum, maize and soybean infected bean, indicated the non-specificity of the pathogen. It was concluded that severity of disease and percentage of dead plants preemergence could be useful criteria 
for selecting resistant bean germplasm to $M$. phaseolina in early stages of growth.

However, due to the lack of studies, the effects of the previously mentioned factors on susceptibility of cottonseed to $M$. phaseolina are unclear. Therefore, the objective of this study was to evaluate the effects of inoculum density, temperature, incubation period, and isolate on susceptibility of seed from some of the Egyptian cottons (Gossypium barbadense L.) to $M$. phaseolina.

\section{MATERIALS AND METHODS}

\section{Isolates of $M$. phaseolina}

Isolates of $M$. phaseolina used in the following studies were obtained from the fungal collection of Cotton Disease Research Section, Plant Pathology Research Institute, Agric. Res. Center. These isolates were originally isolated from cotton roots as well as from roots of other hosts of $M$. phaseolina.

\section{Effect of inoculum density on susceptibility of cottonseed to $M$. phaseolina}

Substrate for growth of a highly pathogenic isolate of $M$. phaseolina was prepared in 500-ml glass bottles, each bottle contained $100 \mathrm{~g}$ of sorghum grains and $80 \mathrm{ml}$ of tap water. Contents of each bottle were autoclaved for 30 minutes. Isolate inoculum, taken from one-week-old culture on PDA, was aseptically introduced into the bottle and allowed to colonize sorghum for three weeks. The present study was carried out by using autoclaved clay loam soil. Soil was infested with M. phaseolina inoculum at a rate of 10 and $50 \mathrm{~g} / \mathrm{kg}$ of soil. In the control treatment, autoclaved sorghum grains were mixed thoroughly with soil at a rate of 10 or $50 \mathrm{~g} / \mathrm{kg}$ of soil. Infested and noninfested soils were dispensed in 10-cm-diameter clay pots and these were planted with 10 seed per pot (cultivar Giza 75). The pots were randomly distributed on a greenhouse bench. The prevailing temperatures during the experiment were $22.5 \pm 0.5$ (minimum) and $30.5 \pm 0.5$ (maximum). Twenty five seeds were randomly removed from soil each six hrs. and used for isolation on PDA. There were five pots (replicates) for each sampling interaval.

Effects of temperature, incubation period, isolate, and their interactions on susceptibility of cottonseed to $M$. phaseolina

Three isolates, differing in their pathogenicity, were used in this study. The isolates were weakly pathogenic, moderately pathogenic, and highly pathogenic. Batches of autoclaved clay loam soil were separately infested with inoculum of each isolate at a rate of $50 \mathrm{~g} / \mathrm{kg}$ of soil. Infested soil was dispensed in 15-cm-diameter clay pots and these were planted with 15 seeds per pot for each of the tested cultivars (Giza 75, Giza 80, and Giza 85). Pots were randomly distributed on greenhouse benches under four temperature regimes (Table 1). There were four pots (replicates) for each treatment. Seeds or radicles of germinating seeds were randomly removed from soil after 24, 48, 72, and $96 \mathrm{hr}$. from planting and used for isolation on PDA. 
Table 1: Temperature regimes $\left({ }^{\circ} \mathrm{C}\right)$ and incubation periods $(\mathrm{hr})$ used in studying the effects of temperature, incubation period, isolate and their interactions on susceptibility of cotton seeds to $M$. phaseolina.

\begin{tabular}{cccc}
\hline $\begin{array}{c}\text { Treatment } \\
\text { No. }\end{array}$ & \multicolumn{2}{c}{ Temperature regime } & $\begin{array}{c}\text { Incubation } \\
\text { period } \\
\text { (hr) }\end{array}$ \\
\cline { 2 - 3 } & Min. & Max. & $24,48,72,96$ \\
\hline T1 & $27.5 \pm 3.5$ & $38.5 \pm 0.5$ & $24,48,72,96$ \\
T2 & $25 \pm 1$ & $35 \pm 1$ & $24,48,72,96$ \\
T3 & $22.5 \pm 0.5$ & $30.5 \pm 0.5$ & $24,48,72,96$ \\
T4 & $18 \pm 0.0$ & $25.5 \pm 0.5$ & \\
\hline
\end{tabular}

\section{Statistical analysis of the data}

The experimental design of all studies was a randomized complete block with four or five replicates. Analysis of variance (ANOVA) of the data was performed with the MSTAT-C Statistical Package. Least significant difference (LSD) was used to compare treatment means. Regression analysis was performed with a computerized program.

\section{RESULTS AND DISCUSSION}

\section{Effect of inoculum density on susceptibility of cottonseed to $M$. phaseolina}

Cottonseeds were removed from infested soil every six hours and used for isolation on PDA. Results shown in Table (2) indicated that the higher the inoculum density, the earlier the isolation of MP from seeds and the higher its isolation frequency.

Table 2:Effect of inoculum density on susceptibility of cotton (cultivar Giza 75) to M. phaseolina.

\begin{tabular}{lcc}
\hline $\begin{array}{l}\text { Inoculum } \\
\text { Density }\end{array}$ & $\begin{array}{l}\text { Time (hr) required for } \\
\text { colonization of seeds }\end{array}$ & $\begin{array}{c}\text { Isolation } \\
\text { frequency }\end{array}$ \\
\hline $1 \%$ & 96 & $4 \%$ \\
$5 \%$ & 12 & $12 \%$
\end{tabular}

Effects of temperature, incubation period, isolate, and their interactions on susceptibility of cottonseed to $M$. phaseolina

ANOVA (Table 3) showed that the three main effects of this study (temperature, incubation period, and isolate) were all very highly significant sources of variation in susceptibility of cotton seed to $M$. phaseolina regardless of the tested cultivar. The two-way interaction for temperature $x$ incubation period was a very highly significant source of variation in the case of cultivars Giza $75(P=0.0000)$ and Giza $80(P=0.0001)$, while it was a nonsignificant source of variation $(P=0.2925)$ in the case of Giza 85. All the other sources of variation were nonsignificant $(P>0.05)$ regardless of the tested cultivar. 
Table 3: Analysis of variance of the effects of temperature regime, incubation period, isolate and their interaction on isolation frequency of $M$. phaseolina from seeds of three cotton cultivars.

\begin{tabular}{|c|c|c|c|c|}
\hline Source of variation & D. $F$ & M. S & F- value & $P>F$ \\
\hline \multicolumn{5}{|c|}{ Giza 75} \\
\hline Temperature regime $(\mathrm{T})$ & 3 & 1091.519 & 15.9403 & 0.0000 \\
\hline Incubation period $(\mathrm{P})$ & 3 & 4157.836 & 60.7203 & 0.0000 \\
\hline TxP & 9 & 880.015 & 12.8516 & 0.0000 \\
\hline Isolates (S) & 2 & 9164.365 & 133.8348 & 0.0000 \\
\hline TxS & 6 & 59.185 & 0.8643 & \\
\hline PxS & 6 & 25.229 & 0.3684 & \\
\hline TxPxS & 18 & 75.819 & 1.1073 & \\
\hline \multirow{2}{*}{\multicolumn{5}{|c|}{ Giza 80}} \\
\hline & & & & \\
\hline Temperature regime $(\mathrm{T})$ & 3 & 327.678 & 4.4695 & 0.0064 \\
\hline Incubation period $(\mathrm{P})$ & 3 & 8411.917 & 114.7376 & 0.0000 \\
\hline TxP & 9 & 300.001 & 4.0920 & 0.0001 \\
\hline Isolates (S) & 2 & 5098.703 & 69.5457 & 0.0000 \\
\hline TxS & 6 & 75.297 & 1.0270 & 0.4090 \\
\hline PxS & 6 & 153.828 & 2.0982 & 0.0552 \\
\hline TxPxS & 18 & 38.646 & 0.5271 & \\
\hline Error & 192 & 73.314 & & \\
\hline \multicolumn{5}{|c|}{ Giza 85} \\
\hline Temperature regime $(\mathrm{T})$ & 3 & 1238.073 & 18.8412 & 0.0000 \\
\hline Incubation period $(\mathrm{P})$ & 3 & 4460.693 & 67.8835 & 0.0000 \\
\hline $\operatorname{TxP}$ & 9 & 79.332 & 1.2073 & 0.2925 \\
\hline Isolates (S) & 2 & 5406.890 & 82.2828 & 0.0000 \\
\hline TxS & 6 & 137.501 & 2.0925 & 0.0559 \\
\hline PxS & 6 & 89.900 & 1.3681 & 0.2294 \\
\hline TxPxS & 18 & 103.257 & 1.5714 & 0.0707 \\
\hline Error & 192 & 65.711 & & \\
\hline
\end{tabular}

Relative contribution of each source of variation to variation in isolation frequency of $M$. phaseolina from seeds is shown in Table (4). Incubation period was the first in importance as a source of variation in isolation frequency from Giza 80 and Giza 85 . It accounted for $61.27 \%$ of the explained (model) variation in isolation frequency from Giza 80 and $42.02 \%$ from Giza 85. In the case of Giza 75, isolate was the first in importance as a source of variation in isolation frequency followed by incubation period. Isolate was the second in importance as a source of variation in isolation frequency from Giza 80 and Giza 85 . The highest relative contribution of temperature $\mathrm{x}$ incubation period interaction to variation in isolation frequency was observed in the case of Giza 75. 
Table 4: Relative contribution of temperature regime, incubation period, isolate and their interaction on isolation frequency of $M$. phaseolina from seeds of three cotton cultivars.

\begin{tabular}{|c|c|c|c|}
\hline \multirow{2}{*}{ Source of variation } & \multicolumn{3}{|c|}{$\begin{array}{l}\text { Relative contribution a to variation in isolation } \\
\text { frequency of } M \text {. phaseolina from seeds of }\end{array}$} \\
\hline & Giza 75 & Giza 80 & Giza 85 \\
\hline $\begin{array}{l}\text { Temperature regime }(T) \\
\text { incubation period }(\mathrm{P}) \\
\text { TxP } \\
\text { Isolate }(\mathrm{S}) \\
\text { TxS } \\
\text { PXS } \\
\text { TXPXS }\end{array}$ & $\begin{array}{l}7.46 \\
28.43 \\
18.05 \\
41.78 \\
0.81 \\
0.35 \\
3.11\end{array}$ & $\begin{array}{l}2.39 \\
61.27 \\
6.56 \\
24.76 \\
1.10 \\
2.24 \\
1.69\end{array}$ & $\begin{array}{l}11.66 \\
42.02 \\
2.24 \\
33.26 \\
2.59 \\
1.69 \\
5.84\end{array}$ \\
\hline
\end{tabular}

${ }^{a}$ calculated as percentage of sum of squares of the explained (model) variation

Table 5: Effect of temperature regime, incubation period, isolate and their interactions on isolation frequency of $M$. phaseolina from seeds of cotton cultivar Giza 75.

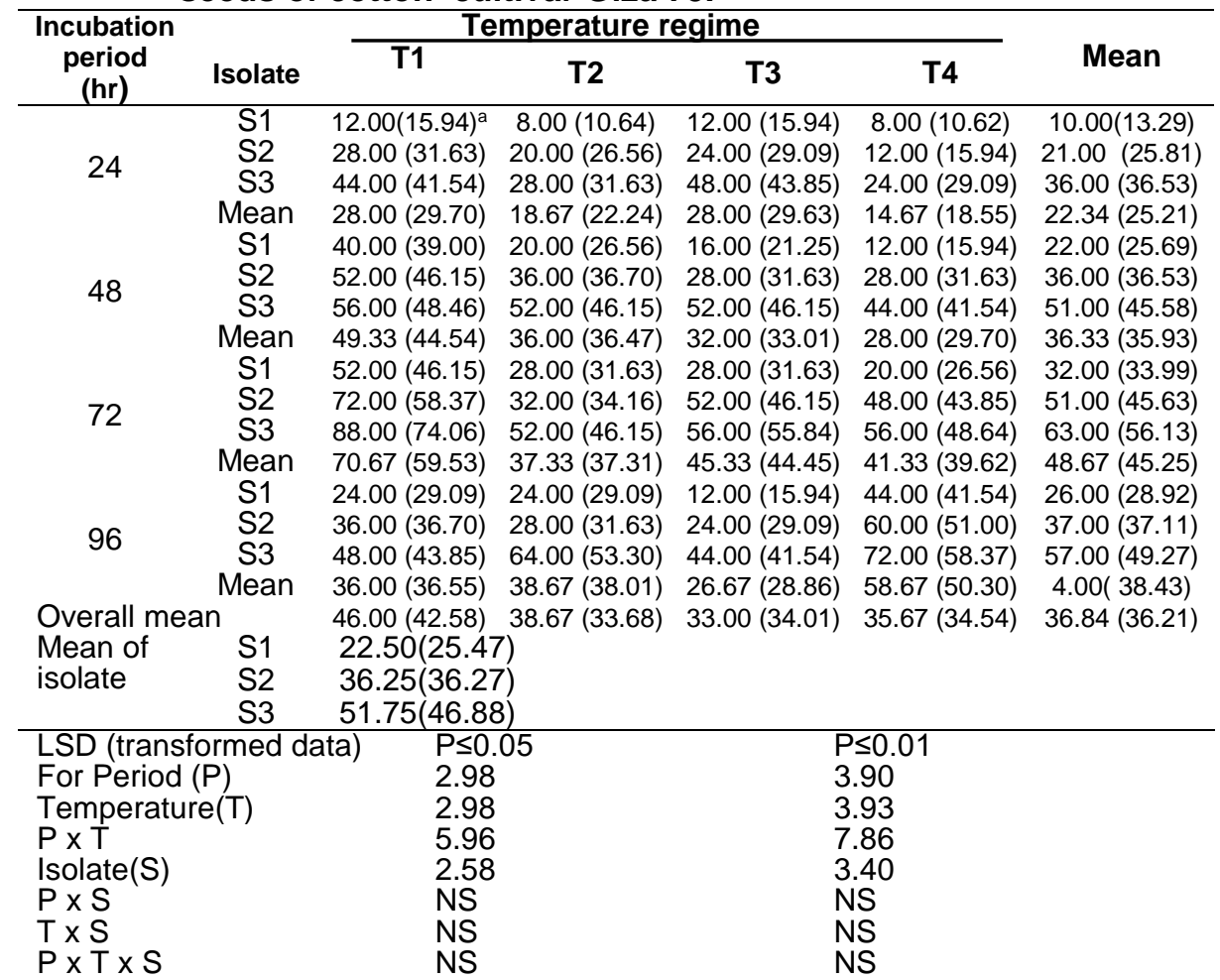

a Mean of five replicates. Percentage data were transformed into arc sine angles before carrying out the analysis of variance. Transformed means are shown in parentheses.

Due to the significant interaction between temperature regime and incubation periods in the case of Giza 75, a least significant difference (LSD) was used to compare between the incubation periods within temperature regimes. These comparisons showed that the magnitude of the difference between incubation periods was affected by temperature regime (Table 5). For example, the increase of incubation period from $24 \mathrm{hr}$ to $48 \mathrm{hr}$ caused highly 
significant increase in the isolation frequency under the first temperature regime; however, the increase in isolation frequency was nonsignificant under the third temperature regime. Similarly, the increase of incubation period from $48 \mathrm{hr}$ to $72 \mathrm{hr}$ caused highly significant increase in isolation frequency under the first temperature regime, however, almost no increase in isolation frequency was observed under the second temperature regime. Under the first temperature regime, the increase of incubation period from $72 \mathrm{hr}$ to $96 \mathrm{hr}$ caused an appreciable decrease in isolation frequency, while it caused an appreciable increase in isolation frequency under the fourth temperature regime.

Due to the significant interaction between temperature regime and incubation period in the case of Giza 80, a LSD was used to compare between the incubation periods within temperature regimes. These comparisons showed that the magnitude of the difference between incubation periods was affected by temperature regime (Table 6). For example, the increase of incubation period from $48 \mathrm{hr}$ to $72 \mathrm{hr}$ caused highly significant increase in the isolation frequency under the first temperature regime; however, the increase in isolation frequency was nonsignificant under the second temperature regime.

[Table 6: Effects of temperature regime, incubation period, isolate and their interactions on isolation frequency of $M$. phaseolina from seeds of cotton cultivar Giza 80.

\begin{tabular}{|c|c|c|c|c|c|c|}
\hline \multirow{2}{*}{$\begin{array}{c}\text { Incubation } \\
\text { period } \\
(\mathrm{hr})\end{array}$} & \multirow[b]{2}{*}{ Isolate } & \multicolumn{3}{|c|}{ Temperature regime } & \multirow[b]{2}{*}{ T4 } & \multirow{2}{*}{ Mean } \\
\hline & & T1 & T2 & T3 & & \\
\hline \multirow{4}{*}{24} & S1 & $12.00(15.94)^{\mathrm{a}}$ & 12.00(15.94) & $8.00(10.62)$ & $4.00(5.31)$ & $9.00(11.25)$ \\
\hline & S2 & $20.00(26.56)$ & $16.00(21.25)$ & $(12.00)(15.4)$ & $8.00(10.62)$ & $14.00(18.9)$ \\
\hline & S3 & $32.00(34.16)$ & $24.00(29.09)$ & $24.00(29.09)$ & $20.00(23.78)$ & $25.00(29.03)$ \\
\hline & Mean & $21.33(25.55)$ & $17.33(22.09)$ & $14.00(18.55)$ & $10.67(13.24)$ & $15.83(19.86)$ \\
\hline \multirow{4}{*}{48} & $\mathrm{~S} 1$ & $20.00(26.56)$ & $24.00(29.09)$ & $16.00(21.25)$ & $8.00(10.62)$ & $16.50(21.88)$ \\
\hline & S2 & $32.00(34.16)$ & $28.00(31.63)$ & $24.00(29.09)$ & $16.00(21.25)$ & $25.00(29.03)$ \\
\hline & S3 & $36.00(36.70)$ & $36.00(36.70)$ & $44.00(41.54)$ & $36.00(36.69)$ & $38.00(37.91)$ \\
\hline & Mean & 29.33(32.47) & $29.33(32.47)$ & $28.00(30.63)$ & $20.00(22.85)$ & $26.67(29.61)$ \\
\hline \multirow{4}{*}{72} & S1 & $36.00(36.70)$ & $24.00(29.09)$ & $28.00(31.63)$ & $24.00(29.09)$ & $28.00(31.63)$ \\
\hline & 32 & $52.00(46.15)$ & $32.00(34.16)$ & $48.00(43.85)$ & $36.00(36.69)$ & $42.00(40.21)$ \\
\hline & S3 & $72.00(58.37)$ & $52.00(46.16)$ & $60.00(51.00)$ & $60.00(55.84)$ & $61.00(52.84)$ \\
\hline & Mean & 53.33(47.07) & $36.00(36.47)$ & $45.33(42.16)$ & $40.00(40.54)$ & $43.67(41.55)$ \\
\hline \multirow{3}{*}{96} & & $44.00(41.54)$ & $32.00(34.16)$ & $44.00(41.54)$ & $48.00(43.85)$ & $42.00(40.27)$ \\
\hline & S2 & $52.00(46.15)$ & $48.00(43.85)$ & $56.00(48.46)$ & $64.00(53.53)$ & $55.00(48.00)$ \\
\hline & S3 & $52.00(46.15)$ & $56.00(48.69)$ & $56.00(48.46)$ & $68.00(55.84)$ & $58.00(49.79)$ \\
\hline & Mean & 49.33(44.61) & $45.33(42.23)$ & $52.00(46.15)$ & $60.00(51.07)$ & $51.67(46.02)$ \\
\hline \multicolumn{2}{|c|}{ Overall mean } & $38.33(37.43)$ & $32.00(33.32)$ & $34.83(34.37)$ & $32.67(31.93)$ & $34.46(34.26)$ \\
\hline $\begin{array}{l}\text { Mean of } \\
\text { isolate }\end{array}$ & $\begin{array}{l}\text { S1 } \\
\text { S2 } \\
\text { S3 }\end{array}$ & $\begin{array}{l}23.88(26.43) \\
34.00(33.96) \\
45.50(42.39\end{array}$ & & & & \\
\hline \multicolumn{2}{|c|}{ LSD (transformed data } & \multirow{2}{*}{\multicolumn{2}{|c|}{$\mathrm{P} \leq 0.05$}} & \multicolumn{2}{|c|}{$\mathrm{P} \leq 0.01$} & \\
\hline \multirow{2}{*}{\multicolumn{2}{|c|}{$\begin{array}{l}\text { For Period }(\mathrm{P}) \\
\text { Temperature }(\mathrm{T})\end{array}$}} & 3.08 & & \multirow{2}{*}{\multicolumn{2}{|c|}{$\begin{array}{l}4.07 \\
4.07\end{array}$}} & \\
\hline & & & & & \\
\hline \multirow{2}{*}{\multicolumn{2}{|c|}{$\begin{array}{l}\mathrm{P} \times \mathrm{T} \\
\text { Isolate(S) }\end{array}$}} & \multirow{2}{*}{\multicolumn{2}{|c|}{$\begin{array}{l}6.17 \\
2.67\end{array}$}} & & \\
\hline & & & & \multicolumn{2}{|c|}{3.52} & \\
\hline \multicolumn{2}{|c|}{$\begin{array}{l}T \times S \\
P \times S\end{array}$} & \multicolumn{2}{|l|}{ NS } & \multirow{2}{*}{\multicolumn{2}{|c|}{$\begin{array}{l}\text { NS } \\
\text { NS }\end{array}$}} & \\
\hline \multirow{2}{*}{\multicolumn{2}{|c|}{$\begin{array}{l}T \times S \\
P \times T \times S\end{array}$}} & \multirow{2}{*}{\multicolumn{2}{|c|}{$\begin{array}{l}\text { NS } \\
\text { NS }\end{array}$}} & & & \\
\hline & & & & Ns & & \\
\hline
\end{tabular}


Due to the lack of a significant interaction between incubation period and temperature regime in the case of Giza 85, a LSD was calculated to compare between the general means of incubation periods and temperature regimes (Table 7). The highest isolation frequency of $M$. phaseolina from seeds was found when the seeds were incubated in infested soil for 72 hours. The increase of the incubation period to $96 \mathrm{hr}$ did not significantly increase the isolation frequency of $M$. phaseolina from seeds. Seeds yielded the highest frequency of $M$. phaseolina when they were incubated under the $2^{\text {nd }}$ and the $3^{\text {rd }}$ temperature regimes.

Table 7: Effects of temperature regime, incubation period, isolate and their interactions on isolation frequency of $M$. phaseolina from seeds cotton cultivar Giza 85.

\begin{tabular}{|c|c|c|c|c|c|c|}
\hline \multirow{2}{*}{$\begin{array}{l}\text { Incubatior } \\
\text { period } \\
\text { (hr) }\end{array}$} & \multirow[b]{2}{*}{ Isolate } & \multicolumn{3}{|c|}{ Temperature regime } & \multirow[b]{2}{*}{ T4 } & \multirow[b]{2}{*}{ Mean } \\
\hline & & T1 & $\mathrm{T} 2$ & T3 & & \\
\hline \multirow{4}{*}{24} & S1 & $8.00(10.62)^{a}$ & $16.00(21.25)$ & $12.00(15.94)$ & $12.00(15.94)$ & $12.00(15.94)$ \\
\hline & & $12.00(15.94)$ & $20.00(26.56)$ & $20.00(26.56)$ & 16.00 & 17.00 (22.85) \\
\hline & S3 & $24.00(29.09)$ & $28.00(31.63)$ & $36.00(36.70)$ & $24.00(29.09)$ & $28.00(31.63)$ \\
\hline & Mean & $14.67(18.55)$ & $21.33(26.48)$ & $22.67(26.40)$ & $17.33(22.09)$ & 19.00 (23.38) \\
\hline \multirow{4}{*}{48} & & $16.00(21.25)$ & $24.00(29.09)$ & $20.00(26.56)$ & 12.00 & 18.00 (23.21) \\
\hline & S2 & $16.00(21.25)$ & $36.00(34.16)$ & 28.00 (31.63) & $20.00(26.56)$ & $25.00(28.40)$ \\
\hline & & $28.00(31.63)$ & $40.00(39.00)$ & $52.00(46.15)$ & $28.00(31.63)$ & $37.00(37.10)$ \\
\hline & Mean & $20.00(24.71)$ & $33.33(34.08)$ & 33.33 (34.78) & $20.00(24.71)$ & $26.67(29.57)$ \\
\hline \multirow{3}{*}{72} & & $32.00(34.16)$ & $28.00(31.63)$ & $28.00(31.63)$ & $24.00(29.09)$ & $28.00(31.83)$ \\
\hline & 32 & $32.00(34.16)$ & $32.00(34.10)$ & $52.00(46.15)$ & $28.00(31.63)$ & $36.00(36.51)$ \\
\hline & S3 & $48.00(43.85)$ & 72.00 (58.37) & $64.00(53.30)$ & $68.00(55.84)$ & $63.00(52.84)$ \\
\hline \multirow{5}{*}{96} & Mean & 37.33 (37.39) & $44.00(41.37)$ & 48.00 (43.69) & 40.00 & 42.33 \\
\hline & & $28.00(31.63)$ & $32.00(34.16)$ & 44.00 & 28.00 & $33.00(34.74)$ \\
\hline & $\mathrm{S}$ & $32.00(34.16)$ & $52.00(46.15)$ & $56.00(48.46)$ & $28.00(31.63)$ & $42.00(40.10)$ \\
\hline & & $32.00(34.16)$ & $52.00(46.15)$ & 72.00 (58.37) & $68.00(55.84)$ & $56.00(48.63)$ \\
\hline \multirow{2}{*}{\multicolumn{2}{|c|}{ Overall mean }} & $30.67(33.32)$ & $45.33(42.15)$ & $57.33(49.46)$ & $41.33(39.70)$ & $43.67(41.16)$ \\
\hline & & $25.67(28.49)$ & $36.00(63.02)$ & $40.33(38.58)$ & 29.67 (31.34) & $32.92(33.61)$ \\
\hline $\begin{array}{l}\text { Mean of } \\
\text { isolate }\end{array}$ & $\begin{array}{l}\text { S1 } \\
\text { S2 }\end{array}$ & $\begin{array}{l}22.75(26.43) \\
30.00(31.90) \\
46.00(4255\end{array}$ & & & & \\
\hline \multicolumn{2}{|c|}{$\begin{array}{l}\text { LSD (transformed dat } \\
\text { For Period }(\mathrm{P}) \\
\text { Temperature }(\mathrm{T}) \\
\text { PxT } \\
\text { Isolate }(\mathrm{S}) \\
\text { PxS } \\
\text { TxS } \\
\text { PxTxS }\end{array}$} & \multicolumn{2}{|c|}{$\begin{array}{l}P \leq 0.05 \\
2.92 \\
2.92 \\
\text { NS } \\
2.53 \\
\text { NS } \\
\text { NS } \\
\text { NS }\end{array}$} & \multicolumn{2}{|c|}{$\begin{array}{l}P \leq 0.01 \\
3.85 \\
3.85 \\
\text { NS } \\
3.34 \\
\text { NS } \\
\text { NS } \\
\text { NS }\end{array}$} & \\
\hline
\end{tabular}

a Mean of five replicates. Percentage data were transformed into arc sine angles before carrying out the analysis of variance. Transformed means are shown in parentheses.

The isolates of $M$. phaseolina maintained their ranking regardless of the tested cultivar. Thus, S1 was the least aggressive isolate in colonization of seeds, while S3 was the most aggressive isolate. S2 was intermediate in aggressiveness (Tables 5, 6, and 7). 
Abdel-Sattar, M. A. et al.

A highly positive linear relationship was found between incubation period and isolation frequency $(P<0.01)$. $R^{2}$ of the regression model was 0.83 when the inoculum density was $1 \%$ and increased to 0.96 when the inoculum density was $5 \%$ (Figs. 1 and 2 ).

The results of the present study demonstrated that colonization of cotton seeds by $M$. phaseolina during the early stages of infection was affected by inoculum density, temperature, incubation period (time of seed exposure to inoculum), and pathogenicity of isolates. The findings of this study highlight the importance of some cultural practices in controlling $M$. phaseolina on cotton. For example, in normal cropping sequence of cotton it would not be desirable to introduce soybean, which would tend to increase the M. phaseolina inoculum density (Kenerley and Jeger, 1992). Burying and subsequent decomposition of the residues from previous crops may aid in controlling $M$. phaseolina by reducing population of the pathogen in the residues through antibiosis (Watkins, 1981). Control of $M$. phaseolina may be achieved by preventive measures such as acid delinting and coating seeds with protective fungicides, which prevent infection when the seeds are sown in infested soil. It is also recommended to avoid extreme high temperature through early sowing.

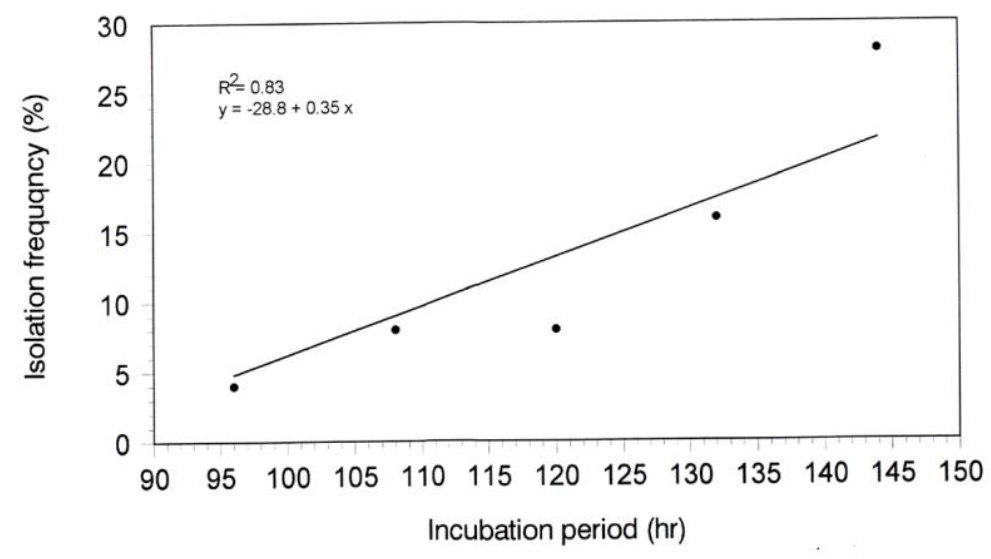

Figure 1: Relationship between incubation period of cotton seeds (cv. Giza 75) in autoclaved soil infested with $M$. phaseolina and frequency of the fungus isolated from these seeds. The autoclaved soil was infested with $M$. phaseolina at the rate of $1 \%(w / w)$. 


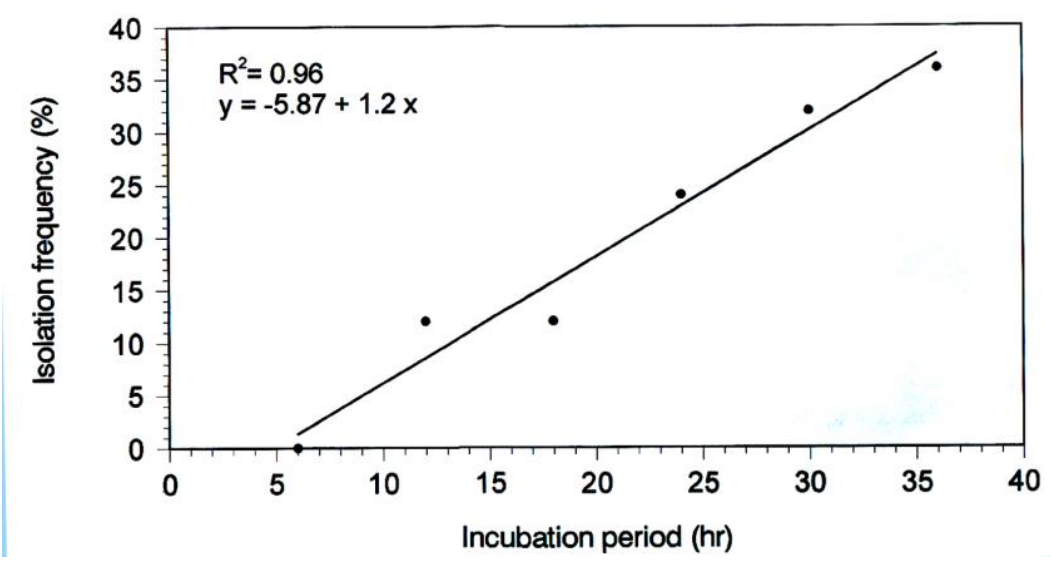

Figure 2: Relationship between incubation period of cotton seeds (cv Giza 75) in autoclaved soil infested with M. phaseolina and frequency of the fungus isolated from these seeds. The autoclaved soil was infested with $M$. phaseolina at the rate of $5 \%(w / w)$.

\section{REFERENCES}

Aly, A.A., E.M. Hussein, M.A. Mostafa, and A.I. Ismail. 1996. Distribution, identification, and pathogenicity of Fusarium spp. isolated from some Egyptian cottons. Menofiya J. Agric. Res. 21: 819-836.

Dhingra, O.D., and J.B. Sinclair. 1978. "Biology and pathology of Macrophomina phaseolina". Imprensia Universidade Federal de Viscosa, Brazil $166 \mathrm{p}$.

Diourte, M. 1987. Pathogenic variation and morphological studies of Macrophomina phaseolina (Tossi) Goid. M.Sc. Thesis, Texas A and M Univ. 48p.

Diourte, M., J.L. Starr, M.J. Jeger, J.P. Stack and D.T. Rosenow. 1995. Charcoal rot (Macrophomina phaseolina) resistance and the effects of water stress on disease development in sorghum. Plant Pathology 44: 196-202.

Gupta, I.J. and H.S. Cheema. 1990. Effect of microsclerotia of Macrophomina phaseolina and seed dressers on germination and vigour of sesame seed. Seed Research 18: 169-172.

Hooda, I., and R.K. Grover. 1988. Effect of age, quantity of inoculum, and isolates of Macrophomina phaseolina on the pathogenesis of mungbean and its control by chemicals. Indian Phytopathology 41: 107-117.

Kenerley, C.M. and M.J. Jeger. 1992. Fungal diseases of the root and stem. pp. 161-190. In: Cotton Diseases (R.J. Hillocks, ed). C.A.B. International, Wallingford. 
Lee, C.C., L.S. Bird, P.M. Thaxton, and M.L. Howell. 1986. The association of Macrophomina phaseolina with cotton. Acta Phytophylactica Sinica 13: 169-173.

Manici, L.M., F. Caputo, and C. Cerato. 1995. Temperature responses of isolates of Macrophomina phaseolina from different climatic regions of sunflower production in Italy. Plant Disease 79: 834-838.

Mayek-Perez, N., C. Lopez-Castaneda, and J.A. Acosta-Gallegos. 1997. Variation in in vitro cultural characteristics of Macrophomina phaseolina isolates and its virulence on common beans. Agrociencia 31: 187-195.

Mohamed, H.A. 1962. Effect of date of planting on fungi and other microorganisms isolated from cotton seedlings. Plant Dis. Reptr. 46:801-803.

Mostafa, M.A. 1959. Review of fungal diseases of cotton in Egypt. Egypt. Rev. Sci. 3:1-55.

Mostafa, M.A., M.S. Naim, and S.K. Moawad. 1957. Studies in the interaction between Fusarium oxysporum (Schlecht) and Macrophomina phaseoli (Maubl.) in parasitizing "Karnak" and "Giza 30" cotton varieties and in culture. I. Comparative cultural studies of Fusarium and Macrophomina. $3^{\text {rd }}$ Arab Sci. Cong. 57-67.

Mukhopadhyay, M., S. Kundu, and K.R. Samaddar. 199I. Increased susceptibility of mungbean to Macrophomina phaseolina at low temperature. Journal of Mycopathological Research 29: 1-7.

Omar, M.R. 1999. Studies on susceptibility of cotton to Macrophomina phaseolina. M.Sc. Thesis, Al-Azhar Univ. Cairo. 139p.

Patel, K.K. and A.J. Patel. 1990. Meteorological correlation of charcoal rot of sesame. Indian Journal of Mycology and Plant Pathology 20: 64-65.

Pearson, C.A.S. ,and F.W. Schwenk. 1986. Variable chlorate resistance in Macrophomina phaseolina from corn, soybean and soil. Phytopathology 76: 646-649.

Pineda, J., R. Nass, and H. Rodriguez. 1985. Effect of the inoculum density of Macrophomina phaseolina on infection of sesame seedlings. Agronomia Tropical 35: 133-138.

Rana, R.S., and N.N. Tripathi. 1984. Influence of inoculum, host, and soil environment on the incidence of collar rot of Indian mustard. Indian Journal of Mycology and Plant Pathology 14: 223-228.

Ratnoo, R.S., K.L. Jain, and M.K. Bhatnagar. 1997a. Effect of atmospheric temperature on the development of ash-gray stem blight of cowpea. Journal of Mycology and Plant Pathology 27: 90-91.

Ratnoo, R.S., K.L. Jain, and M.K. Bhatnagar. 1997b. Variation in Macrophomina isolates of ash-gray stem blight of cowpea. Journal of Mycology and Plant Pathology 27: 91-92.

Rettinasababady, C., N. Ramadoss, and T. Ramanadare. 2000. Effect of different inoculum levels of Macrophomina phaseolina (Tassi) Goid on seed rot of blackgram. Seed Research 28: 232-234.

Sabet, K.A. and L.D. Khan. 1969. Competitive saprophytic ability and inoculum potential of cotton root-infecting fungi in five soils. Cott. Grow Rev. 46:113-119. 
Umamaheswari, C., G. Ramakrishnan,and P. Nllathambi. 2000. Role of inoculum level on disease incidence of dry root rot caused by Macrophomina phaseolina in groundnut. Madras Agricultural Journal. 87: 71-73.

Viana, F.M.P., and N.L. De-Souza. 1997. Effect of temperature and water tension of the substrate on germination of microsclerotia of Macrophomina phaseolina. Summa Phytopathologica 23: 236-239.

Viana, F.M.P., and N.L. De-Souza. 2002. Effect of temperature-water tension interaction on germination of Macrophomina phaseolina microsclerotia. Fitopatologia Brasileira 27: 268-272.

Vilela, V., M. Delpilar, and J.A.M. Delgado. 1987. Characterization patogenicay cultural de diferentes aislemientos de Macrophomina phaseolina (Tassi) Goid., agenta causal de la pudriccion carbonosa de laraiz del algodonero (Gossypium barbadense L.) en las condicioues de Piura, Peru, Fitopatologia 22: 1-9.

Watkins, G.M. ed. 1981. Compendium of cotton diseases. The American Phytopathological Society. St. Paul., Minnesota. 87p.

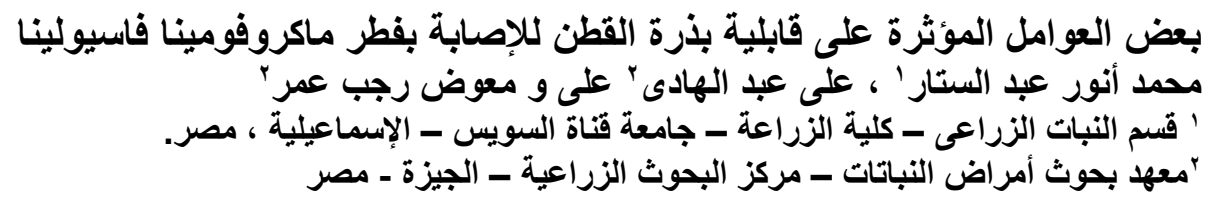

إن استعمار بذرة القطن بفطر ماكروفومينا فاسيولينا خلال المراحل المبكرة من الإصابة العزابة

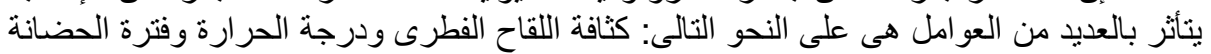

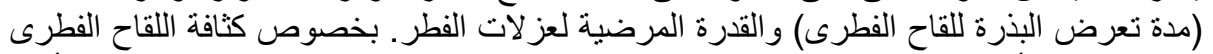

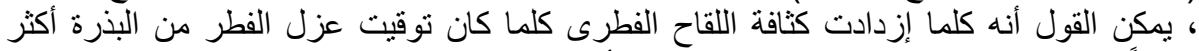

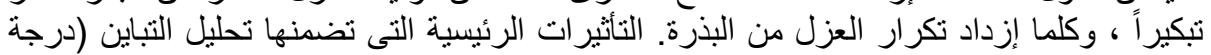

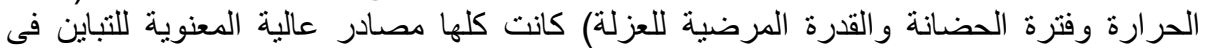

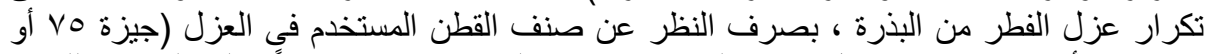

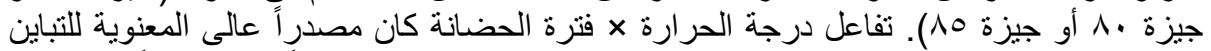

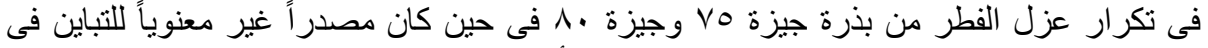

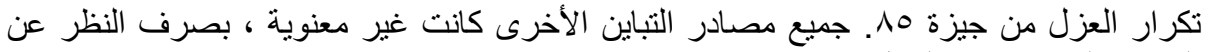
الصنف المستخدم فى العزل. 